\title{
PENERAPAN METODE ANALYTICAL HIERARCHY PROCESS (AHP) UNTUK PENENTUAN KOLEKTOR TERBAIK PADA PT. ANUGRAH ARGON MEDICA BOGOR
}

\author{
Dedy Mulyadi ${ }^{1}$, Desy Riris Marpaung ${ }^{2}$ \\ ${ }^{1}$ Program Studi Sistem Informasi STIKOM Binaniaga, Bogor, Indonesia \\ dedymulyadi@stikombinaniaga.ac.id \\ ${ }^{2}$ PT. Anugrah Argon Medica, Bogor, Indonesia \\ desyriris91@gmail.com
}

\begin{abstract}
PT. Anugrah Argon Medica is a developing company that is engaged in the distributor of pharmaceuticals and medical devices. This company was founded in 1980. PT. Anugrah Argon Medica has people who work in it who are often called employees, and the employees discussed here are in the billing section or collectors. So far the role of a collector at PT. Anugrah Argon Medica can be said to be enough to support collection or collection of money that has been billed to relations. But the lack of appreciation given by companies can indirectly affect their work productivity. Therefore it is necessary to have an award aimed at the best collectors, of course those who have contributed to the collection or collection results generated. From the results of the AHP calculation that has been done, the recommendation for selecting the best collector is Aldi, which has the highest value, namely the value of 2.01 then D (Yusuf) with a value of 1.90 then $C$ (Rachmadi) with a value of 1.30 and $B$ (Jaenudin) with a value of 1.02 and the lowest value is E (Wawan) with a value of 0.92. By using the AHP method, it can be proven that this method can be recommended as a decision support tool in determining the best collector selection at PT. Anugrah Argon Medica.
\end{abstract}

Keywords: Analytical Hierarchy Process (AHP), Determination of the Best Collector.

\begin{abstract}
ABSTAK
Perusahaan PT. Anugrah Argon Medica merupakan perusahaan berkembang yang bergerak dalam bidang distributor farmasi dan alat kesehatan. Perusahaan ini berdiri sejak 1980. PT. Anugrah Argon Medica memiliki orang-orang yang berkerja di dalamnya yang sering disebut karyawan, dan karyawan yang dibahas di sini adalah di bagian penagihan atau yang disebut kolektor. Sejauh ini peranan seorang kolektor di PT. Anugrah Argon Medica sudah bisa dikatakan cukup untuk bisa menopang collection atau hasil pengumpulan uang yang telah ditagih ke relasi. Namun kurangnya apresiasi yang diberikan oleh perusahaan secara tidak langsung dapat mempengaruhi produktivitas kerja mereka. Oleh karena itu dibutuhkan adanya sebuah penghargaan yang ditujukan kepada kolektor terbaik, tentunya mereka yang telah memberikan kontribusinya terhadap hasil collection atau penagihan yang dihasilkan. Dari hasil perhitungan AHP yang telah dilakukan maka rekomendasi pemilihan kolektor terbaik adalah Aldi yang memiliki nilai paling tinggi yaitu dengan nilai 2,01 lalu D (Yusuf) dengan nilai 1,90 selanjutnya $C$ (Rachmadi) dengan nilai 1,30 dan B (Jaenudin) dengan nilai 1,02 dan nilai terendah yaitu $E$ (Wawan) dengan nilai 0,92. Dengan menggunakan metode AHP, maka dapat dibuktikan bahwa metode ini dapat direkomendasikan sebagai alat penunjang keputusan dalam menentukan pemilihan kolektor terbaik pada PT. Anugrah Argon Medica.
\end{abstract}

Kata Kunci: Analytical Hierarchy Process (AHP), Penentuan Kolektor Terbaik. 


\section{PENDAHULUAN}

\section{Latar Belakang Masalah}

Penilaian berhasil atau tidaknya suatu perusahaan, tidak hanya dilihat dari seberapa besar perkembangannya, tetapi juga dilihat dari seberapa besar usaha perusahaan dalam memperhatikan kepentingan karyawan, dimana hal ini berkaitan dengan kepuasaan kerja yang dirasakan setiap karyawan.

Perusahaan PT. Anugrah Argon Medica merupakan perusahaan berkembang yang bergerak dalam bidang distributor farmasi dan alat kesehatan. Perusahaan ini berdiri sejak 1980. PT. Anugrah Argon Medica memiliki orang-orang yang berkerja di dalamnya yang sering disebut karyawan, dan karyawan yang dibahas di sini adalah di bagian penagihan atau yang disebut kolektor.

Sejauh ini peranan seorang kolektor di PT. Anugrah Argon Medica sudah bisa dikatakan cukup untuk bisa menopang collection atau hasil pengumpulan uang yang telah ditagih ke relasi. Namun kurangnya apresiasi yang diberikan oleh perusahaan secara tidak langsung dapat mempengaruhi produktivitas kerja mereka. Oleh karena itu dibutuhkan adanya sebuah penghargaan yang ditujukan kepada kolektor terbaik, tentunya mereka yang telah memberikan kontribusinya terhadap hasil collection atau penagihan yang dihasilkan.

\section{Rumusan Masalah}

\section{Identifikasi Masalah}

Permasalahan yang terjadi saat ini pada PT.Anugrah Argon Medica yaitu belum optimalnya pemilihan kolektor yang diterapkan oleh departemen administrasi. Saat ini mereka hanya menggunakan data pencapaian collection dari setiap kolektor untuk menentukan pemilihan kolektor terbaik. Tetapi ada beberapa kolektor yang tidak memenuhi target. Hal ini yang menjadi permasalahan yang dialami departemen admisnistrasi dalam menentukan kolektor terbaiknya.

\section{Problem Statement (Pernyataan Masalah)}

Belum diketahui kriteria dan bobot penilaian yang digunakan untuk pemilihan kolektor terbaik pada PT. Anugrah Argon Medica cabang Bogor.

\section{Research Question (Pertanyaan Penelitian)}

Bagaimana penerapan metode AHP untuk menentukan kriteria kolektor terbaik pada PT. Anugrah Argon Medica cabang Bogor.

\section{METODE PENELITIAN}

\section{Desain Penelitan}

Penelitian yang dilakukan adalah penelitian penerapan metode AHP untuk menentukan pemilihan kriteria kolektor terbaik pada PT. Anugrah Argon Medica. Dimana, ruang lingkup objek penelitian yang akan digunakan yaitu pada perusahaan sebagai pelaksana. Adapun tahapan-tahapan yang dilakukan dalam proses pemecahan masalah dalam menentukan kolektor terbaik adalah :

\section{Tahap Identifikasi Masalah}

Pada tahap ini dilakukan identifikasi terhadap permasalahan yang ada, dari permasalahan tersebut akan dicari metode apa yang bisa diterapkan, kemudian dilakukan penelitian dan uji coba untuk membuktikan metode tersebut. 


\section{Tahap Pengumpulan Data}

Pengumpulan data dengan cara mengambil bahan-bahan dari kajian literature untuk mendapatkan informasi yang mendukung dengan permasalahan yang dibahas, dari pengumpulan data ini peneliti memperoleh data apa saja yang akan diperlukan dalam penelitian yang akan dilakukan yaitu:
a. Observasi
b. Wawancara
c. Kuesioner
d. Studi Literature

3. Tahapan Analisa dan Hasil

Terdapat 2 (dua) kegiatan tahap, dalam tahap analisa dan kesimpulan ini, diantaranya adalah sebagai berikut:

a. Analisa data dengan metode AHP

Analisa ini dilakukan untuk memperoleh nilai masing-masing kriteria yang diperoleh dari hasil penyebaran kuesioner.

b. Hasil

Setelah dilakukan analisa diperoleh urutan-urutan dari prioritas kriteria yang dapat digunakan untuk pemilihan kolektor tebaik.

\section{Instrumen Penelitian}

Menurut Sumadi Suryabrata (2008, p.52) instrumen penelitian adalah alat atau fasilitas yang telah digunakan oleh peneliti dalam mengumpulkan data agar pekerjaan lebih mudah, kemudian hasilnya pun lebih baik dalam arti lebih cermat, lengkap dan sistematis sehingga lebih mudah diolah. Pada penelitian ini menggunakan kuesioner sebagai instrumen peneltian, penyebaran kuesioner ini dilakukan untuk mengetahui kriteria prioritas dan alternatif proritas. Kuesioner adalah perangkat untuk menggali data primer dari responden sebagai sumber data terpenting dalam peneltian. Metode ini dillakukan untuk memberikan pembobotan terhadap kriteria pembanding yang dibuat sedemikian rupa sehingga mudah dipahami.

\section{Metode Pengumpulan Data}

Metode yang dilakukan dalam proses penelitian dengan cara melakukan pendekatan pada teknik pengumpulan data yaitu:

1. Observasi

Metode observasi adalah metode pengumpulan data yang akan dilakukan dengan melihat dan mengadakan pengamatan secara langsung terhadap perusahaan. Observasi dilakukan secara mendalam untuk mengetahui secara detail proses pemilihan kriteria kolektor terbaik pada PT. Anugrah Argon Medica Bogor.

2. Wawancara

Merupakan suatu cara untuk mendapatkan data atau informasi dengan tanya jawab secara langsung pada orang yang mengetahui tentang objek yang diteliti di PT.Anugrah Argon Medica Bogor khususnya departemen administrasi.

3. Kuesioner

Kuesioner digunakan dalam mengukur sejauh mana peranan objek penelitian untuk dapat menunjang proses pengambilan keputusan. Adapun tujuan ini yaitu mencari informasi dari responden mengenai suatu masalah penelitian. Kuesioner disebarkan untuk memberikan pembobotan terhadap kriteria dan alternatif pembanding. Jenis daftar kuesioner yang disebarkan 
kepada responden adalah daftar pertanyaan tertutup (kuesioner berstruktur) yang didalamnya disajikan sedemikian rupa sehingga responden diminta untuk memilih satu jawaban yang sesuai dengan analisisnya.

4. Studi Literature

Studi literature dalam penelitian ini adalah untuk mendapatkan gambaran dengan menelusuri sumber-sumber tulisan yang pernah dibuat sebelumnya seperti jurnal ilmiah dari hasil penelitian mahasiswa lainnya.

\section{Sumber data}

Data yang akan digunakan dalam penelitian ini adalah data primer. Menurut Umar (2003, p.56), data primer merupakan data yang diperoleh langsung di lapangan oleh peneliti sebagai objek penulisan. Sedangkan sumber data sekunder merupakan sumber yang tidak langsung memberikan sumber data kepada pengumpul data. Metode wawancara dan kuesioner dipergunakan untuk memperoleh data. Data yang diambil dari kuesioner akan disebarkan pada kepala administrasi, inkaso dan supervisor yang merupakan karyawan PT. Anugrah Argon Medica Bogor.

\section{Analisa Data}

Analisa data dlakukan dengan menghitung consistensy ratio (CR) dengan rumus yaitu:

$$
C R=\frac{C I}{I R}
$$

$\mathrm{CR}=$ Consistensy Ratio

$\mathrm{CI}=$ Consistensy Index

$\mathrm{IR}=$ Index Random Consistensy

\section{HASIL DAN PEMBAHASAN}

\section{Penentuan Kriteria}

Kriteria adalah ukuran yang menjadi dasar penilaian dalam menentukan pemilihan kolektor terbaik. Untuk menetapkan kriteria yang menjadi acuan dalam menentukan kolektor terbaik dilakukan dengan menyebarkan kuesioner kepada 4 orang karyawan sebagai pengambil keputusan yaitu supervisor dan inkaso PT. Anugrah Argon Medica. Dari hasil penyebaran kuesioner tersebut didapatkan 4 kriteria yang terpilih.

Adapun 5 kriteria tersebut adalah:

1. Absensi

Dokumen yang mencatat kehadiran setiap karyawan di sebuah perusahaan, dalam hal ini kehadiran kolektor d PT. Anugran Argon Medica.

2. Perilaku

Menurut Notoatmodjo, 2003, perilaku adalah semua kegiatan atau aktivitas manusia, baik yang diamati langsung, maupun yang tidak dapat diamati oleh pihak luar. Dengan kata lain setiap perilaku dari kolektor akan dinilai oleh perusahaan untuk dijadikan pertimbangan penentuan operator terbaik.

3. Pencapaian

Jumlah hasil tagihan yang telah dikumpulkan oleh setiap kolektor.

4. Tanggung jawab

Kewajiban dari setiap kolektor untuk menyelesaikan tugas dan pekerjaannya. 


\section{Penentuan Alternatif}

Merupakan tahapan menentukan pilihan diantara dua atau beberapa kemungkinan yang ada, serta ukuran yang menjadi dasar penilaian dalam menentukan alternatif prioritas yang digunakan dalam penelitian ini yaitu :
1. Aldi
2. Jaenudin
3. Rachmadi
4. Wawan
5. Yusuf

\section{Hirarki}

Penyusunan hirarki adalah dengan menetapkan tujuan yang merupakan sasaran sistem secara keseluruhan pada level atas. Berikut adalah hirarki AHP (Analytical Hierarchy Process) yang menggambarkan kriteria dan alternatif yang akan digunakan.

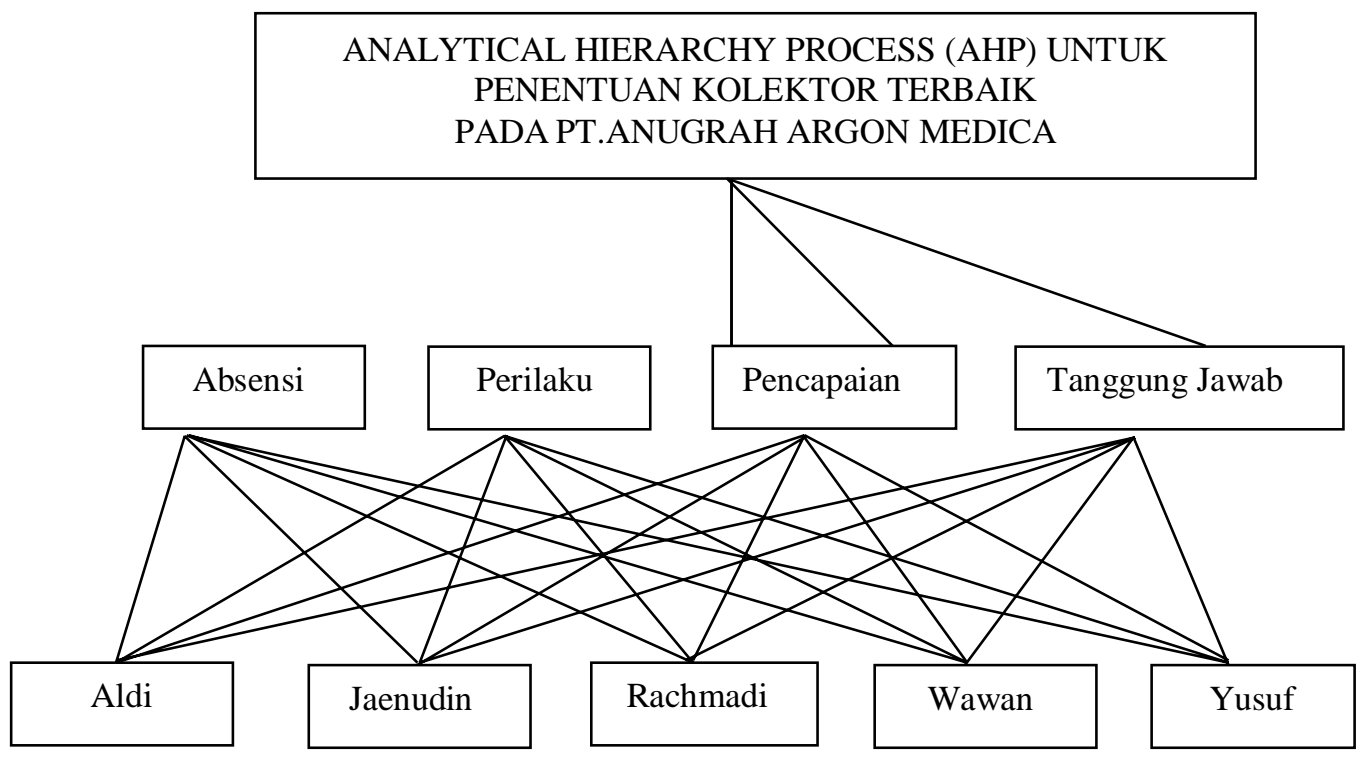

Gambar 1. Struktur Hirarki

Berdasarkan hirarki pada gambar diatas dapat digambarkan goal (tujuan) dalam penelitian ini, adapun goal (tujuan) penelitian ini adalah untuk penentuan kolektor terbaik pada PT. Anugrah Argon Medica.

\section{Hasil Rekapitulasi}

\section{Hasil Rekapitulasi}

\section{a. Rekapitulasi Data Kriteria}

Berdasarkan hasil dari kuesioner yang sudah disebar kepada 4 responden, dapat dilihat di tabel rekapitulasi data kriteria. Adapun hasil rekapitulasi data kriteria dapat dilihat pada tabel 1 .

Tabel 1. Rekapitulasi Data Kriteria

\begin{tabular}{|l|c|c|c|c|c|c|}
\hline \multicolumn{7}{|c|}{ Rekapitulasi Kriteria Berdasarkan Responden di PT. Anugrah Argon Medica } \\
\hline \multirow{2}{*}{ Kriteria } & \multicolumn{7}{|c|}{ Banyaknya Responden } & \multirow{2}{*}{ Kriteria } \\
\cline { 2 - 6 } & R1 & R2 & R3 & R4 & Rata-rata & \\
\hline Absensi & $1 / 7$ & $1 / 7$ & 9 & 9 & 4,57 & Perilaku \\
\hline
\end{tabular}


Jurnal Ilmiah Teknologi - Informasi dan Sains (TeknolS)

Volume 8 Nomor 1 Bulan Mei 2018 Hal. 61-77

p-ISSN : 2087-3891 dan e-ISSN : 2597-8918

\begin{tabular}{|l|c|c|c|c|c|c|}
\hline \multicolumn{7}{|c|}{ Rekapitulasi Kriteria Berdasarkan Responden di PT. Anugrah Argon Medica } \\
\hline \multirow{2}{*}{ Kriteria } & R1 & R2 & R3 & R4 & Rata-rata & \multirow{2}{*}{ Kriteria } \\
\cline { 2 - 6 } & 7 & 7 & $1 / 7$ & 1 & 3,79 & Pencapaian \\
\hline Absensi & $1 / 8$ & $1 / 7$ & $1 / 7$ & $1 / 9$ & 0,13 & Tanggung jawab \\
\hline Absensi & 8 & 7 & 7 & $1 / 9$ & 5,53 & Pencapaian \\
\hline Perilaku & $1 / 8$ & $1 / 7$ & $1 / 8$ & $1 / 7$ & 0,13 & Tanggung jawab \\
\hline Perilaku & $1 / 8$ & $1 / 7$ & $1 / 8$ & $1 / 8$ & 0,13 & Tanggung jawab \\
\hline Pencapaian & & &
\end{tabular}

b. Menentukan Prioritas Kriteria

Setelah melakukan rekap terhaap kriteria, maka langka selanjutnya adalah dengan membuat matriks perbandingan berpasangan kriteria dimana data yang diperoleh adalah ratarata hasil rekapitulasi yaitu jumlah nilai pada setiap baris dibagi dengan banyaknya responden dalam penelitian ini jumlah 4 responden.

Tabel 2. Matriks Perbandingan Berpasangan Kriteria

\begin{tabular}{|l|c|c|c|c|}
\hline \multicolumn{1}{|c|}{ Kriteria } & Absensi & Perilaku & Pencapaian & $\begin{array}{c}\text { Tanggung } \\
\text { jawab }\end{array}$ \\
\hline Absensi & 1,00 & 4,57 & 3,79 & 0,13 \\
\hline Perilaku & 0,22 & 1,00 & 5,53 & 0,13 \\
\hline Pencapaian & 0,26 & 0,18 & 1,00 & 0,13 \\
\hline Tanggung jawab & 7,69 & 7,69 & 7,69 & 1,00 \\
\hline Total & 9,17 & 13,44 & 18,01 & 1,39 \\
\hline
\end{tabular}

c. Membuat matriks nilai kriteria

Setelah membuat matriks perbandingan berpasangan, maka langkah selanjutnya adalah dengan membuat matriks nilai kriteria dengan cara membagi nilai kolom dengan jumlah masing-masing kolom pada tabel 2, dapat dilihat pada tabel 3.

Tabel 3. Matriks Nilai Kriteria

\begin{tabular}{|l|c|c|c|c|c|}
\hline \multicolumn{1}{|c|}{ Kriteria } & Absensi & Perilaku & Pencapaian & Tanggung jawab & Rata-rata \\
\hline Absensi & 0,11 & 0,34 & 0,21 & 0,09 & 0,19 \\
\hline Perilaku & 0,02 & 0,07 & 0,31 & 0,09 & 0,12 \\
\hline Pencapaian & 0,03 & 0,01 & 0,06 & 0,09 & 0,05 \\
\hline Tanggung jawab & 0,84 & 0,57 & 0,43 & 0,72 & 0,64 \\
\hline
\end{tabular}

Nilai kolom rata pada tabel 3. didapatkan dari penjumlahan pada tiap baris dengan nilai $0,11+0,34+0,21+0,09$ lalu dibagi dengan jumlah kriteria, dalam hal ini berjumlah 4 kriteria.

d. Menentukan matriks penjumlahan setiap baris

Setiap elemen pada tabel 3 dihitungkan dengan perkalian matriks perbandingan berpasangan dengan nilai rata-rata. Hasilnya ditunjukkan seperti tabel 4.

Tabel 4. Matriks Penjumlahan Setiap Baris

\begin{tabular}{|l|c|c|c|c|c|}
\hline \multicolumn{1}{|c|}{ Kriteria } & Absensi & Perilaku & Pencapaian & Tanggung jawab & Jumlah \\
\hline Absensi & 0,19 & 0,57 & 0,18 & 0,08 & 1,02 \\
\hline Perilaku & 0,04 & 0,12 & 0,26 & 0,08 & 0,51 \\
\hline
\end{tabular}


Jurnal Ilmiah Teknologi - Informasi dan Sains (TeknolS)

Volume 8 Nomor 1 Bulan Mei 2018 Hal. 61-77

p-ISSN : 2087-3891 dan e-ISSN : 2597-8918

\begin{tabular}{|l|c|c|c|c|c|}
\hline \multicolumn{1}{|c|}{ Kriteria } & Absensi & Perilaku & Pencapaian & Tanggung jawab & Jumlah \\
\hline Pencapaian & 0,05 & 0,02 & 0,05 & 0,08 & 0,20 \\
\hline Tanggung jawab & 1,45 & 0,96 & 0,37 & 0,64 & 3,41 \\
\hline
\end{tabular}

Kolom jumlah pada tabel 4 diperoleh dari penjumlahan nilai pada masing-masing baris tabel tersebut.

e. Perhitungan rasio konsistensi

Langkah selanjutnya adalah melakukan perhitungan rasio konsistensi, perhitungan ini digunakan untuk memastikan bahwa rasio konsistensi $(\mathrm{CR})<=0.1$, hasil perhitungan dapat dilihat pada tabel berikut.

Tabel 5. Perhitungan Rasio Konsistensi

\begin{tabular}{|l|c|c|c|}
\hline \multicolumn{1}{|c|}{ Kriteria } & Jumlah & Rata-rata & Hasil \\
\hline Absensi & 1,02 & 0,19 & 1,21 \\
\hline Perilaku & 0,51 & 0,12 & 0,63 \\
\hline Pencapaian & 0,20 & 0,05 & 0,25 \\
\hline Tanggung jawab & 3,41 & 0,64 & 4,05 \\
\hline
\end{tabular}

Kolom jumlah pada tabel 5 didapatkan dari kolom jumlah yang terdapat pada tabel 4 , sedangkan kolom rata-rata didapatkan dari kolom rata-rata pada tabel 3, kemudian untuk kolom hasil diperoleh dari perhitungan kolom jumlah ditambahkan dengan kolom rata-rata, berikut untuk perhitungan rasio konsistensi:

$$
\begin{aligned}
& 1,21 / 0,19=6,37 \\
& 0,63 / 0,12=5,25 \\
& 0,25 / 0,05=5,00 \\
& 4,05 / 0,64=\frac{6,33+}{22,95} \\
& \lambda \text { maks }(\text { total } / \mathrm{n}) \quad=22,95 / 4 \\
& =5,74
\end{aligned}
$$

Consistensy Index (CI):

$$
\text { CI } \quad \begin{aligned}
= & (\lambda \text { maks }-\mathrm{n}) / \mathrm{n}-1 \\
& =(5,74-4) / 4-1 \\
& =1,74 / 3 \\
& =0,58
\end{aligned}
$$

Consistensy Ratio (CR):

$\mathrm{CR}=\mathrm{CI} / \mathrm{IR}$

$=0,58 / 0,90$

$=0,01$

Rasio konsitensi dari perhitungan tersebut adalah 0,01, dengan ketentuan CR $<=0.1$, maka rasio konsistensinya dapat diterima.

f. Hasil penentuan rangking prioritas kriteria tabel 6:

Prioritas hasil perhitungan pada langkah 1 sampai 4 kemudian dituangkan seperti 
Tabel 6. Rangking Prioritas Kriteria

\begin{tabular}{|l|c|}
\hline \multicolumn{1}{|c|}{ Kriteria } & Prioritas \\
\hline Tanggung jawab & 4,05 \\
\hline Absensi & 1,21 \\
\hline Perilaku & 0,63 \\
\hline Pencapaian & 0,25 \\
\hline
\end{tabular}

Berdasarkan tabel 6 menunjukkan bahwa kriteria tanggung jawab merupakan kriteria paling penting dengan jumlah 4,05 kemudian kriteria absensi dengan jumlah 1,21 lalu kriteria perilaku dengan jumlah 0,63 dan yang terakhir kriteria pencapaian dengan jumlah 0,25.

\section{Penilaian Alternatif}

Penulis menentukan 5 alternatif dari sekian banyak alternatif yang ada, berikut ini merupakan 5 alternatif untuk pemilihan kolektor, bisa dilihat pada tabel. Dalam hal ini terdapat 4 kriteria yang berarti akan ada 4 perhitungan prioritas alternatif.

Tabel 7. Alternatif Kolektor

\begin{tabular}{|l|c|}
\hline \multicolumn{1}{|c|}{ Alternatif } & Kode \\
\hline Aldi & A \\
\hline Jaenudin & B \\
\hline Rachmadi & C \\
\hline Wawan & D \\
\hline Yusuf & E \\
\hline
\end{tabular}

a. Kriteria tanggung jawab

1) Rekapitulasi Alternatif terhadap Kriteria Tanggung jawab

Dapat dilihat pada tabel 4.8 hasil rekapitulasi alternatif berdasarkan kriteria tanggung jawab.

Tabel 8. Rekapitulasi Alternatif Berdasarkan Kriteria Tanggung jawab

\begin{tabular}{|c|c|c|c|c|c|c|}
\hline \multicolumn{7}{|c|}{ Tanggung jawab } \\
\hline Alternatif & R1 & R2 & R3 & R4 & Rata-rata & Alternatif \\
\hline A & 6 & 1 & 7 & 2 & 4,00 & B \\
\hline A & 6 & 1 & 1 & 2 & 2,50 & C \\
\hline A & $1 / 8$ & 1 & 1 & $1 / 5$ & 0,58 & D \\
\hline $\mathrm{A}$ & 1 & 1 & 7 & 7 & 4,00 & E \\
\hline $\mathrm{B}$ & $1 / 7$ & 1 & $1 / 7$ & 6 & 1,82 & $\mathrm{C}$ \\
\hline $\mathrm{B}$ & $1 / 8$ & 1 & $1 / 7$ & $1 / 7$ & 0,35 & $\mathrm{D}$ \\
\hline $\mathrm{B}$ & 1 & 1 & 7 & 8 & 4,25 & $\mathrm{E}$ \\
\hline $\mathrm{C}$ & $1 / 7$ & 1 & 1 & $1 / 7$ & 0,57 & $\mathrm{D}$ \\
\hline $\mathrm{C}$ & $1 / 6$ & 1 & 7 & $1 / 8$ & 2,07 & $\mathrm{E}$ \\
\hline $\mathrm{D}$ & 8 & 1 & 7 & 7 & 5,75 & $\mathrm{E}$ \\
\hline
\end{tabular}

2) Menghitung prioritas dari kriteria tanggung jawab

Setelah melakukan rekap, maka langkah berikutnya adalah dengan membuat matriks perbandingan berpasangan. 
Tabel 9. Matriks Perbandingan Berpasangan Kriteria Tanggung jawab

\begin{tabular}{|c|c|c|c|c|c|}
\hline Alternatif & A & B & C & D & E \\
\hline A & 1,00 & 4,00 & 2,50 & 0,58 & 4,00 \\
\hline B & 0,25 & 1,00 & 1,82 & 0,35 & 4,25 \\
\hline C & 0,40 & 0,55 & 1,00 & 0,57 & 2,07 \\
\hline D & 1,72 & 2,86 & 1,75 & 1,00 & 5,75 \\
\hline E & 0,25 & 0,24 & 0,48 & 0,17 & 1,00 \\
\hline Jumlah & 3,62 & 8,64 & 7,56 & 2,67 & 17,07 \\
\hline
\end{tabular}

3) Membuat matriks nilai kriteria tanggung jawab

Setelah membuat matriks perbandingan berpasangan, maka langkah selanjutnya adalah dengan membuat matriks nilai kriteria dengan cara membagi nilai baris kolom dengan jumlah masing-masing kolom pada tabel 9, dapat dilihat pada tabel 10.

Tabel 10. Matriks Nilai Kriteria Tanggung jawab

\begin{tabular}{|c|c|c|c|c|c|c|}
\hline Alternatif & A & B & C & D & E & Rata-rata \\
\hline A & 0,28 & 0,46 & 0,33 & 0,22 & 0,23 & 0,30 \\
\hline B & 0,07 & 0,12 & 0,24 & 0,13 & 0,25 & 0,16 \\
\hline C & 0,11 & 0,06 & 0,13 & 0,21 & 0,12 & 0,13 \\
\hline D & 0,48 & 0,33 & 0,23 & 0,37 & 0,34 & 0,35 \\
\hline E & 0,07 & 0,03 & 0,06 & 0,07 & 0,06 & 0,06 \\
\hline
\end{tabular}

Kolom rata-rata diperoleh dari penjumlahan setiap kolom yaitu $0,28+0,46+0,33+0,22+0,23$ lalu dibagi jumlah alternatif yaitu 5 alternatif.

4) Menentukan matriks penjumlahan setiap baris

Setiap elemen pada tabel 9 dengan perkalian matriks perbandingan berpasangan dengan nilai rata-rata pada tabel 10. Hasilnya ditunjukkan seperti pada tabel 11.

Tabel 11. Matriks Penjumlahan Setiap Baris Kriteria Tanggung jawab

\begin{tabular}{|c|c|c|c|c|c|c|}
\hline Alternatif & A & B & C & D & E & Jumlah \\
\hline A & 0,30 & 0,64 & 0,32 & 0,20 & 0,23 & 1,70 \\
\hline B & 0,08 & 0,16 & 0,23 & 0,12 & 0,24 & 0,83 \\
\hline C & 0,12 & 0,09 & 0,13 & 0,20 & 0,12 & 0,66 \\
\hline D & 0,52 & 0,46 & 0,22 & 0,35 & 0,33 & 1,89 \\
\hline E & 0,08 & 0,04 & 0,06 & 0,06 & 0,06 & 0,29 \\
\hline
\end{tabular}

b. Perhitungan rasio konsistensi

Perhitungan ini dilakukan untuk memastikan bahwa nilai rasio konsistensi $(\mathrm{CR})<=$ 0.1. Untuk menghitung rasio konsistensi, dapat terlihat pada tabel 12 :

Tabel 12. Perhitungan Rasio Konsistensi Kriteria Tanggung jawab

\begin{tabular}{|c|c|c|c|}
\hline Alternatif & Jumlah & Rata—rata & Hasil \\
\hline A & 1,70 & 0,30 & 2,00 \\
\hline B & 0,83 & 0,16 & 1,00 \\
\hline C & 0,66 & 0,13 & 0,78 \\
\hline D & 1,89 & 0,35 & 2,24 \\
\hline
\end{tabular}




\begin{tabular}{|c|c|c|c|}
\hline Alternatif & Jumlah & Rata-rata & Hasil \\
\hline E & 0,29 & 0,06 & 0,35 \\
\hline \multicolumn{3}{|c|}{ Total } & 6,37 \\
\hline
\end{tabular}

Berikut untuk perhitungan rasio konsitensi:

$\begin{array}{ll}\mathrm{N} \text { (jumlah alternatif) } & =5 \\ \lambda \text { maks } & =\text { total } / \mathrm{n} \\ & =6,37 / 5 \\ & =1,27\end{array}$

Consistensy Index (CI):

$\mathrm{CI}=(\lambda$ maks $-\mathrm{n}) / \mathrm{n}-1$

$=(1,27-5) / 5-1$

$=-3,37 / 4$

$=-0,93$

Consistensy Ratio (RI):

$\mathrm{CR} \quad=\mathrm{CI} / \mathrm{IR}$

$=-0,93 / 1,12$

$=-0,83$

Matriks pada perhitungan alternatif ini terdiri dari 5 ordo, matriks yang berordo 5 x 5 nilai IR nya adalah 1,12. Rasio konsistensi dari perhitungan tersebut adalah $-0,83$, dengan ketentuan $\mathrm{CR}<=0,1$ maka rasio konsistensinya dapat diterima.

c. Kriteria Pencapaian

1) Rekapitulasi Alternatif terhadap Kriteria Pencapaian

Dapat dilihat pada tabel 13 hasil rekapitulasi alternatif kriteria pencapaian. Data yang diambil 6 bulan terakhir dari januari 2018-juni 2018 lalu diambil rata-rata pencapaian.

Tabel 13. Rekapitulasi Alternatif Berdasarkan Kriteria Pencapaian

\begin{tabular}{|c|c|c|c|c|c|c|c|c|}
\hline \multirow{2}{*}{ Nama Kolektor } & & \multicolumn{6}{|c|}{ PENCAPAIAN (JAN 2018-JUNI 2018) } & \multirow{2}{*}{ PencapaianRata-Rata } \\
\hline & & JAN & FEB & MAR & APR & MEI & JUNI & \\
\hline ALDI & 20094.549 .203 & \begin{tabular}{|l|}
1.593 .310 .628 \\
\end{tabular} & 1.299 .282 .764 & 2.176 .531 .119 & 2.545 .646 .306 & 2.842 .793 .330 & $1.710 .092 .772,92$ & 2.027 .942 .820 \\
\hline JAENUDIN & 487.043 .278 & 638.603 .009 & 561.153 .933 & 485.3247 .726 & 542.257 .282 & 563.773 .358 & $430.724 .533,27$ & 536.972 .807 \\
\hline RACHMADI & 2.761 .620 .165 & 3.057 .335 .395 & 2.108 .850 .540 & 3.081 .140 .885 & 2.369 .200 .597 & 3.088 .778 .723 & $2,537.472 .515,83$ & 2.707 .129 .776 \\
\hline YUSUF & 788.315:497| & 656.842 .008 & 788.538 .516 & 872.130 .495 & 893.799 .897 & 807.712 .830 & $557.123 .855,01$ & 762.691 .267 \\
\hline WAWAN & 3.025 .978 .968 & \begin{tabular}{|l|}
2.694 .791 .404 \\
\end{tabular} & 2.464 .263 .198 & 3.912 .681 .316 & 3.406 .899 .196 & 3.441 .240 .962 & $2.318 .900 .778,42$ & 3.039 .796 .143 \\
\hline
\end{tabular}

2) Menghitung prioritas dari kriteria pencapaian

Setelah melakukan rekap, maka langkah berikutnya adalah dengan membuat matriks perbandingan berpasangan.

Tabel 14. Matriks Perbandingan Berpasangan Kriteria Pencapaian

\begin{tabular}{|c|c|c|c|c|c|}
\hline Alternatif & A & B & C & D & E \\
\hline A & 1,00 & 3,78 & 0,75 & 2,66 & 0,67 \\
\hline B & 0,26 & 1,00 & 0,20 & 0,70 & 0,18 \\
\hline C & 1,33 & 5,04 & 1,00 & 3,55 & 0,89 \\
\hline D & 0,38 & 1,42 & 0,28 & 1,00 & 0,25 \\
\hline
\end{tabular}




\begin{tabular}{|c|c|c|c|c|c|}
\hline Alternatif & A & B & C & D & E \\
\hline E & 1,50 & 5,66 & 1,12 & 3,99 & 1,00 \\
\hline Jumlah & 4,47 & 16,90 & 3,35 & 11,90 & 2,99 \\
\hline
\end{tabular}

3) Membuat matriks nilai kriteria pencapaian

Setelah membuat matriks perbandingan berpasangan, maka langkah selanjutnya adlah dengan membuat matriks nilai kriteria dengan cara membagi nilai baris kolom dengan jumlah masing-masing kolom pada tabel 14, dapat dilihat pada tabel 15.

Tabel 15. Matriks Nilai Kriteria Pencapaian

\begin{tabular}{|c|c|c|c|c|c|c|}
\hline Alternatif & A & B & C & D & E & Rata-rata \\
\hline A & 0,22 & 0,22 & 0,22 & 0,22 & 0,22 & 0,22 \\
\hline B & 0,06 & 0,06 & 0,06 & 0,06 & 0,06 & 0,06 \\
\hline C & 0,30 & 0,30 & 0,30 & 0,30 & 0,30 & 0,30 \\
\hline D & 0,08 & 0,08 & 0,08 & 0,08 & 0,08 & 0,08 \\
\hline E & 0,33 & 0,33 & 0,33 & 0,33 & 0,33 & 0,33 \\
\hline
\end{tabular}

4) Menentukan matriks penjumlahan setiap baris

Setiap elemen pada tabel 15 dihitung dengan perkalian matriks perbandingan berpasangan dengan nilai rata-rata. Hasilnya ditunjukkan seperti tabel 16:

Tabel 16. Matriks Penjumlahan Setiap Baris Kriteria Pencapaian

\begin{tabular}{|c|c|c|c|c|c|c|}
\hline Alternatif & A & B & C & D & E & Jumlah \\
\hline A & 0,22 & 0,22 & 0,22 & 0,22 & 0,22 & 1,12 \\
\hline B & 0,06 & 0,06 & 0,06 & 0,06 & 0,06 & 0,30 \\
\hline C & 0,30 & 0,30 & 0,30 & 0,30 & 0,30 & 1,49 \\
\hline D & 0,08 & 0,08 & 0,08 & 0,08 & 0,08 & 0,42 \\
\hline E & 0,33 & 0,33 & 0,33 & 0,33 & 0,33 & 1,67 \\
\hline
\end{tabular}

5) Perhitungan Konsistensi Rasio

Perhitungan ini dilakukan untuk memastikan bahwa nilai rasio konsistensi (CR) $<=0,1$. Untuk menghitung rasio konsistensi dapat terlihat pada tabel 17:

Tabel 17. Perhitungan Rasio Konsistensi Kriteria Pencapaian

\begin{tabular}{|c|c|c|c|}
\hline Alternatif & Jumlah & Rata-rata & Hasil \\
\hline A & 1,12 & 0,22 & 1,34 \\
\hline B & 0,30 & 0,06 & 0,36 \\
\hline C & 1,49 & 0,30 & 1,79 \\
\hline D & 0,42 & 0,08 & 0,50 \\
\hline E & 1,67 & 0,33 & 2,01 \\
\hline \multicolumn{3}{|c|}{ Total } & 6,00 \\
\hline
\end{tabular}

Berikut untuk perhitungan rasio konsitensi:

$\mathrm{N}$ (jumlah alternatif) $=5$

$\lambda$ maks

$=$ total $/ \mathrm{n}$

$=6,00 / 5$ 
Consistensy Index (CI):

$$
\begin{aligned}
\mathrm{CI} & =(\lambda \operatorname{maks}-\mathrm{n}) / \mathrm{n}-1 \\
& =(1,20-5) / 5-1 \\
& =-3,80 / 4 \\
& =-0,95
\end{aligned}
$$

Consistensy Ratio (RI):

$$
\begin{aligned}
\mathrm{CR} & =\mathrm{CI} / \mathrm{IR} \\
& =-0,95 / 1,12 \\
& =-0,84
\end{aligned}
$$

Matriks pada perhitungan alternatif ini terdiri dari 5 ordo, matriks yang berordo 5 x 5 nilai IR nya adalah 1,12. Rasio konsistensi dari perhitungan tersebut adalah $-0,84$, dengan ketentuan $\mathrm{CR}<=0,1$ maka rasio konsistensinya dapat diterima.

\section{d. Kriteria Perilaku}

1) Rekapitulasi Alternatif terhadap Kriteria Perilaku

Berdasarkan hasil dari kuesioner yang sudah disebar kepada 4 responden, dapat dilihat di tabel rekapitulasi data kriteria. Adapun hasil rekapitulasi data kriteria dapat dilihat pada tabel 18.

Tabel 18. Rekapitulasi Alternatif Berdasarkan Kriteria Perilaku

\begin{tabular}{|c|c|c|c|c|c|c|c|}
\hline \multicolumn{8}{|c|}{ Perilaku } \\
\hline Alternatif & R1 & R2 & R3 & R4 & $\sum$ R & Rata-rata & Alternatif \\
\hline A & 1 & 1 & 7 & 2 & 11,00 & 2,75 & B \\
\hline A & 1 & $1 / 2$ & 9 & 1 & 11,50 & 2,88 & C \\
\hline A & 1 & $1 / 2$ & 9 & 1 & 11,50 & 2,88 & D \\
\hline A & 1 & 1 & 7 & 7 & 16,00 & 4,00 & E \\
\hline B & 1 & 1 & $1 / 7$ & $1 / 2$ & 2,64 & 0,66 & C \\
\hline B & 1 & $1 / 2$ & $1 / 7$ & $1 / 7$ & 1,79 & 0,45 & D \\
\hline B & 1 & 1 & 1 & 2 & 5,00 & 1,25 & E \\
\hline C & 1 & 1 & $1 / 7$ & $1 / 5$ & 2,34 & 0,59 & D \\
\hline C & 1 & 1 & 7 & 7 & 16,00 & 4,00 & E \\
\hline D & 1 & 1 & 7 & 7 & 16,00 & 4,00 & E \\
\hline
\end{tabular}

2) Menghitung prioritas dari kriteria perilaku

Setelah melakukan rekap, maka langkah berikutnya adalah dengan membuat matriks perbandingan berpasangan.

Tabel 19. Matriks Perbandingan Berpasangan Kriteria Perilaku

\begin{tabular}{|c|c|c|c|c|c|}
\hline Alternatif & A & B & C & D & E \\
\hline A & 1,00 & 2,75 & 2,88 & 2,88 & 4,00 \\
\hline B & 0,36 & 1,00 & 0,66 & 0,45 & 1,25 \\
\hline C & 0,35 & 1,51 & 1,00 & 0,59 & 4,00 \\
\hline D & 0,35 & 2,24 & 1,71 & 1,00 & 4,00 \\
\hline E & 0,25 & 0,80 & 0,25 & 0,25 & 1,00 \\
\hline Jumlah & 2,31 & 8,30 & 6,49 & 5,16 & 14,25 \\
\hline
\end{tabular}


3) Membuat matriks nilai kriteria perilaku

Setelah membuat matriks perbandingan berpasangan, maka langkah selanjutnya adalah dengan membuat matriks nilai kriteria dengan cara membagi nilai baris kolom dengan jumlah masing-masing kolom pada tabel 19, dapat dilihat pada tabel 20.

Tabel 20. Matriks Nilai Kriteria Perilaku

\begin{tabular}{|c|c|c|c|c|c|c|}
\hline Alternatif & A & B & C & D & E & Rata-rata \\
\hline A & 0,43 & 0,33 & 0,44 & 0,56 & 0,28 & 0,41 \\
\hline B & 0,16 & 0,12 & 0,10 & 0,09 & 0,09 & 0,11 \\
\hline C & 0,15 & 0,18 & 0,15 & 0,11 & 0,28 & 0,18 \\
\hline D & 0,15 & 0,27 & 0,26 & 0,19 & 0,28 & 0,23 \\
\hline E & 0,11 & 0,10 & 0,04 & 0,05 & 0,07 & 0,07 \\
\hline
\end{tabular}

4) Menentukan matriks penjumlahan setiap baris

Setiap elemen pada tabel 19 dengan perkalian matriks perbandingan berpasangan dengan nilai rata-rata pada tabel 20. Hasilnya ditunjukkan seperti pada tabel 21.

Tabel 21 Matriks Penjumlahan Setiap Baris Kriteria Perilaku

\begin{tabular}{|c|c|c|c|c|c|c|}
\hline Alternatif & A & B & C & D & E & Jumlah \\
\hline A & 0,41 & 0,30 & 0,51 & 0,67 & 0,29 & 0,44 \\
\hline B & 0,15 & 0,11 & 0,12 & 0,10 & 0,09 & 0,11 \\
\hline C & 0,14 & 0,17 & 0,18 & 0,14 & 0,29 & 0,18 \\
\hline D & 0,14 & 0,25 & 0,30 & 0,23 & 0,29 & 0,24 \\
\hline E & 0,10 & 0,09 & 0,04 & 0,06 & 0,07 & 0,07 \\
\hline
\end{tabular}

5) Perhitungan rasio konsistensi

Perhitungan ini dilakukan untuk memastikan bahwa nilai rasio konsistensi (CR) $<=0.1$. Untuk menghitung rasio konsistensi, dapat terlihat pada tabel 22:

Tabel 22. Perhitungan Rasio Konsistensi Kriteria Perilaku

\begin{tabular}{|c|c|c|c|}
\hline Alternatif & Jumlah & Rata-rata & Hasil \\
\hline A & 0,44 & 0,41 & 0,84 \\
\hline B & 0,11 & 0,11 & 0,22 \\
\hline C & 0,18 & 0,18 & 0,36 \\
\hline D & 0,24 & 0,23 & 0,47 \\
\hline E & 0,07 & 0,07 & 0,15 \\
\hline \multicolumn{3}{|c|}{ Total } & 2,05 \\
\hline
\end{tabular}

Berikut untuk perhitungan rasio konsitensi:

$\mathrm{N}$ (jumlah alternatif) $=5$

$\lambda$ maks

$=$ total $/ \mathrm{n}$

$=2,05 / 5$

$=0.41$

Consistensy Index (CI):

$\mathrm{CI}=(\lambda \operatorname{maks}-\mathrm{n}) / \mathrm{n}-1$ 


$$
\begin{aligned}
= & (0,41-5) / 5-1 \\
= & -4,59 / 4 \\
= & -1,14 \\
\text { Consistensy } & \text { Ratio }(\mathrm{RI}): \\
\mathrm{CR} \quad & \mathrm{CI} / \mathrm{IR} \\
= & -1,14 / 1,12 \\
= & -1,01
\end{aligned}
$$

Matriks pada perhitungan alternatif ini terdiri dari 5 ordo, matriks yang berordo 5 x 5 nilai IR nya adalah 1,12. Rasio konsistensi dari perhitungan tersebut adalah $-1,01$, dengan ketentuan $\mathrm{CR}<=0,1$ maka rasio konsistensinya dapat diterima.

e. Kriteria Absensi

1) Rekapitulasi alternatif terhadap kriteria absensi

Dapat dilihat pada tabel 23 hasil rekapitulasi alternatif kriteria absensi. Data yang diambil 6 bulan terakhir dari januari 2018-juni 2018 lalu diambil rata-rata absensi.

Tabel 23. Rekapitulasi Alternatif berdasarkan kriteria Absensi

\begin{tabular}{|c|l|c|c|c|c|c|c|c|c|}
\hline \multirow{2}{*}{ No } & \multirow{2}{*}{$\begin{array}{c}\text { Nama } \\
\text { Kolektor }\end{array}$} & \multirow{3}{*}{ Kode } & \multicolumn{5}{|c|}{ Absensi (Jan 2018-Juni 2018) } & \multirow{2}{*}{$\begin{array}{c}\text { Absens } \\
\text { i Rata- } \\
\text { rata }\end{array}$} \\
\cline { 4 - 9 } & & & JAN & FEB & MAR & APR & MEI & JUNI & \\
\hline 1. & ALDI & A & 26 & 23 & 25 & 24 & 24 & 22 & 24 \\
\hline 2. & JAENUDIN & $\mathrm{B}$ & 26 & 23 & 20 & 22 & 24 & 20 & 23 \\
\hline 3. & RACHMADI & $\mathrm{C}$ & 22 & 22 & 22 & 23 & 21 & 15 & 21 \\
\hline 5. & YUSUF & $\mathrm{D}$ & 26 & 23 & 25 & 24 & 24 & 22 & 24 \\
\hline 4. & WAWAN & $\mathrm{E}$ & 26 & 23 & 25 & 24 & 24 & 22 & 24 \\
\hline
\end{tabular}

2) Menghitung prioritas dari kriteria absensi

Setelah melakukan rekap, maka langkah berikutnya adalah dengan membuat matriks perbandingan berpasangan

Tabel 24. Matriks Perbandingan Berpasangan Kriteria Absensi

\begin{tabular}{|c|c|c|c|c|c|}
\hline Alternatif & A & B & C & D & E \\
\hline A & 1,00 & 1,07 & 1,15 & 1,00 & 1,00 \\
\hline B & 0,94 & 1,00 & 1,08 & 0,94 & 0,94 \\
\hline C & 0,87 & 0,93 & 1,00 & 0,87 & 0,87 \\
\hline D & 1,00 & 1,07 & 1,15 & 1,00 & 1,00 \\
\hline E & 1,00 & 1,07 & 1,15 & 1,00 & 1,00 \\
\hline Jumlah & 4,81 & 5,13 & 5,54 & 4,81 & 4,81 \\
\hline
\end{tabular}

3) Membuat matriks nilai kriteria absensi

Setelah membuat matriks perbandingan berpasangan, maka langkah selanjutnya adlah dengan membuat matriks nilai kriteria dengan cara membagi nilai baris kolom dengan jumlah masing-masing kolom pada tabel 24, dapat dilihat pada tabel 25.

Tabel 25. Matriks Nilai Kriteria Absensi

\begin{tabular}{|l|l|l|l|l|l|l|}
\hline Alternatif & A & B & C & D & E & Rata-rata \\
\hline
\end{tabular}


Jurnal Ilmiah Teknologi - Informasi dan Sains (TeknolS)

Volume 8 Nomor 1 Bulan Mei 2018 Hal. 61-77

p-ISSN : 2087-3891 dan e-ISSN : 2597-8918

\begin{tabular}{|c|c|c|c|c|c|c|}
\hline Alternatif & A & B & C & D & E & Rata-rata \\
\hline A & 0,21 & 0,21 & 0,21 & 0,21 & 0,21 & 0,21 \\
\hline B & 0,20 & 0,20 & 0,20 & 0,20 & 0,20 & 0,20 \\
\hline C & 0,18 & 0,18 & 0,18 & 0,18 & 0,18 & 0,18 \\
\hline D & 0,21 & 0,21 & 0,21 & 0,21 & 0,21 & 0,21 \\
\hline E & 0,21 & 0,21 & 0,21 & 0,21 & 0,21 & 0,21 \\
\hline
\end{tabular}

4) Menentukan matriks penjumlahan setiap baris

Setiap elemen pada tabel 25 dihitung dengan perkalian matriks perbandingan berpasangan dengan nilai rata-rata. Hasilnya ditunjukkan seperti tabel 26:

Tabel 26. Matriks Penjumlahan Setiap Baris Kriteria Absensi

\begin{tabular}{|c|c|c|c|c|c|c|}
\hline Alternatif & A & B & C & D & E & Jumlah \\
\hline A & 0,04 & 0,04 & 0,04 & 0,04 & 0,04 & 0,21 \\
\hline B & 0,04 & 0,04 & 0,04 & 0,04 & 0,04 & 0,20 \\
\hline C & 0,04 & 0,04 & 0,03 & 0,04 & 0,04 & 0,18 \\
\hline D & 0,04 & 0,04 & 0,04 & 0,04 & 0,04 & 0,21 \\
\hline E & 0,04 & 0,04 & 0,04 & 0,04 & 0,04 & 0,21 \\
\hline
\end{tabular}

5) Perhitungan Konsistensi Rasio

Perhitungan ini dilakukan untuk memastikan bahwa nilai rasio konsistensi (CR) $<=0.1$. Untuk menghitung rasio konsistensi, dapat terlihat pada tabel 27:

Tabel 27. Perhitungan Rasio Konsistensi Kriteria Absensi

\begin{tabular}{|c|c|c|c|}
\hline Alternatif & Jumlah & rata-rata & Hasil \\
\hline A & 0,21 & 0,21 & 0,42 \\
\hline B & 0,20 & 0,20 & 0,39 \\
\hline C & 0,18 & 0,18 & 0,36 \\
\hline D & 0,21 & 0,21 & 0,42 \\
\hline E & 0,21 & 0,21 & 0,42 \\
\hline \multicolumn{3}{|l|}{ Total } & 2,00 \\
\hline
\end{tabular}

Berikut untuk perhitungan rasio konsitensi:

$\mathrm{N}$ (jumlah alternatif) $=5$

$\lambda$ maks

$$
\begin{aligned}
& =\text { total } / \mathrm{n} \\
& =2,00 / 5 \\
& =0.41
\end{aligned}
$$

Consistensy Index (CI):

$$
\text { CI } \quad \begin{aligned}
= & (\lambda \text { maks }-\mathrm{n}) / \mathrm{n}-1 \\
& =(0,4-5) / 5-1 \\
& =-4,6 / 4 \\
& =-1,14
\end{aligned}
$$

Consistensy Ratio (RI):

$$
\begin{aligned}
\mathrm{CR} & =\mathrm{CI} / \mathrm{IR} \\
& =-1,14 / 1,12 \\
& =-1,15
\end{aligned}
$$

Matriks pada perhitungan alternatif ini terdiri dari 5 ordo, matriks yang 
berordo 5 x 5 nilai IR nya adalah 1,12. Rasio konsistensi dari perhitungan tersebut adalah $-1,15$, dengan ketentuan $\mathrm{CR}<=0,1$ maka rasio konsistensinya dapat diterima.

\section{Konsistensi Logis}

Berdasarkan penilaian terhadap kriteria dan alternatif yang sudah dilakukan pada langkah A dan B, telah dilakukan perhitungan terhadap ratio konsistensi untuk mengetahui seberapa baik konsistensi yang ada, hasilnya dapat dilihat pada tabel 28 .

Tabel 28. Perhitungan Rasio Konsistensi

\begin{tabular}{|l|c|}
\hline Penilaian & Rasio Konsistensi \\
\hline Kriteria & 0,01 \\
\hline Kriteria Tanggung jawab terhadap Alternatif & $-0,83$ \\
\hline Kriteria Pencapaian terhadap Alternatif & $-0,84$ \\
\hline Kriteria Perilaku terhadap Alternatif & $-1,01$ \\
\hline Kriteria Absensi terhadap Alternatif & $-1,15$ \\
\hline
\end{tabular}

Setelah dilakukan pengujian konsistensi logis yang memenuhi persyaratan yaitu CR <= 0,1 maka hasil prioritas yang diperoleh dari perhitungan masing-masing kriteria terhadap alternatif dituangkan ke dalam matriks hasil seperti pada tabel 29.

Tabel 29. Matriks Hasil

\begin{tabular}{|c|c|c|c|c|}
\hline \multirow{2}{*}{ Alternatif } & \multicolumn{4}{|c|}{ Kriteria } \\
\cline { 2 - 5 } & Tanggung jawab & Absensi & Perilaku & Pencapaian \\
\hline A & 0,30 & 0,21 & 0,41 & 1,12 \\
\hline B & 0,16 & 0,20 & 0,11 & 0,30 \\
\hline C & 0,15 & 0,18 & 0,18 & 1,49 \\
\hline D & 0,34 & 0,21 & 0,23 & 0,42 \\
\hline E & 0,05 & 0,21 & 0,07 & 1,67 \\
\hline
\end{tabular}

Lalu dilakukan pencarian hasil akhir dengan mengalikan nilai masing- masing baris 1 pada tabel 29 dengan nilai baris pada tabel 4.6 rangking prioritas kriteria dan menjumlahkan hasilnya seperti pada contoh sebagai berikut:

$=(4,05 * 0,30)+(1,21 * 0,21)+(0,63 * 0,41)+(0,25 * 1,12)$

Lakukan perhitungan yang sama pada baris 2, sampai baris 5 pada tabel dengan nilai baris 2 sampai dengan baris 5 pada tabel rangking kriteria sehingga diperoleh hasil seperti pada tabel 30 .

Tabel 30. Prioritas Hasil

\begin{tabular}{|c|c|}
\hline Alternatif & Nilai \\
\hline A & 2,01 \\
\hline B & 1,02 \\
\hline C & 1,30 \\
\hline D & 1,90 \\
\hline E & 0,92 \\
\hline
\end{tabular}

Dari tabel 30 dapat dijelaskan bahwa A (Aldi) yang memiliki nilai paling tinggi yaitu 
dengan nilai 2,01 lalu D (Yusuf) dengan nilai 1,90 selanjutnya C (Rachmadi) dengan nilai 1,30 dan B (Jaenudin) dengan nilai 1,02 dan nilai terendah yaitu $\mathrm{E}$ (Wawan) dengan nilai 0,92.

\section{KESIMPULAN DAN SARAN}

\section{Kesimpulan}

Berdasarkan hasil penelitian yang telah dilakukan maka dapat disimpulkan bahwa:

1. Dari hasil perhitungan AHP yang telah dilakukan maka rekomendasi pemilihan kolektor terbaik adalah Aldi yang memiliki nilai paling tinggi yaitu dengan nilai 2,01 lalu D (Yusuf) dengan nilai 1,90 selanjutnya C (Rachmadi) dengan nilai 1,30 dan B (Jaenudin) dengan nilai 1,02 dan nilai terendah yaitu $\mathrm{E}$ (Wawan) dengan nilai 0,92 .

2. Dengan menggunakan metode AHP, maka dapat dibuktikan bahwa metode ini dapat direkomendasikan sebagai alat penunjang keputusan dalam menentukan pemilihan kolektor terbaik pada PT. Anugrah Argon Medica.

\section{Saran}

Dari hasil penelitian ini, penulis menyampaikan saran terhadap penelitian selanjutnya yaitu:

1. Diharapkan metode dalam penelitian lebih lanjut untuk menggunakan bahasa pemrograman seperti berbasis website akan lebih mudah untuk dipublikasikan dan di sampaikan kepada pengguna sehingga mempermudah pengguna dalam mendapatkan informasi.

2. Berdasarkan hasil peneltiian perhitungan metode AHP, diharapkan kedepannya metode ini bisa digunakan dengan jumlah alternatif dan kriteria yang lebih banyak.

\section{DAFTAR RUJUKAN}

Firdaus, I. H., dan Gunawan Abdilah, Faiza Renaldi. (2015). Sistem Pendukung Keputusan Penentuan Karyawan Terbaik Menggunakan Metode AHP dan TOPSIS.

Kusrini. 2007 Konsep dan Aplikasi Sistem Pendukung Keputusan, Andi, Yogyakarta.

Sandrena. (2015). Penerapan Metode Analitycal Hierarchy Process (AHP) untuk Optimalisasi Pemilihan Komputer di Perusahaan Smart Solution.

Simanjorang, R. Mahdalena., Harvei Desmon Hutahaean, Hengki Tamando Sihotang. (2017). Sistem Pendukung Keputusan Penentuan Penerima Bahan Pangan Bersubsidi untuk Keluarga Miskin dengan Metode AHP.

Taylor III, Bernard W. (2005). Introduction to Management Science edisi 8 Sains Manajemen: Penerbit Salemba Empat.

Utama, Ditdit Nugeraha. (2017). Sistem Penunjang Keputusan: Filosofi Teori dan Implementasi.

Wahyudi, Ari. (2015). Penerapan Metode Analitycal Hierarchy Process (AHP) untuk Optimalisasi Pemilihan Operator SDD Terbaik pada PT. COATS INDONESIA.

Yuliani, I Dewa Ayu Eka. (2013). Sistem Pendukung Keputusan Pemilihan Karyawan Terbaik dengan Menggunakan Metode Analitycal Hierarchy Process (AHP).

Zulfian. (2014). Penerapan Metode Analitycal Hierachy Process (AHP) untuk Menentukan Kriteria Pemilihan Karyawan Terbaik pada PT. OFFISTARINDO ADHIPRIMA. 